\title{
SOCIAL SUPPORT AND MARITAL ADJUSTMENT IN MARRIED WORKING WOMEN
}

\author{
Mehfooz Ahmad $^{1 *}$, Aqeel Khan ${ }^{2}$ \\ ${ }^{1}$ Clinical Psychologist, Bijnor UP 246701 \\ ${ }^{2}$ School of Education, Universiti Teknologi Malaysia (UTM), Skudai, 81310, Johor, Malaysia \\ *Corresponding Author Email: mehfooz.alig@gmail.com
}

This is an open access article distributed under the Creative Commons Attribution License, which permits unrestricted use, distribution, and reproduction in any medium, provided the original work is properly cited

\section{ARTICLE DETAILS}

\section{Article History:}

Received 26 June 2018 Accepted 2 July 2018 Available online 1 August 2018

\section{ABSTRACT}

Social support is associated with numerous psychological benefits, such as improved self-confidence, sense of empowerment, efficiency, and quality of life. Marital adjustment is the state in which there is an overall feeling between husband and wife, of happiness and satisfaction with their marriage and with each other. Present study aimed at examining social support and marital adjustment in married working women. The demographic data sheet, Multidimensional Scale of Perceived Social Support (MSPSS) and Marital Adjustment Questionnaire were administered on 64 married working women participants age ranging from 25-40 years. The result revealed that family, friends and overall social support were significantly correlated with the marital adjustment in married working women. These finding can be used to remove marital adjustment difficulties prevailing in the society.

\section{KEYWORDS}

social support, marital adjustment, working women

\section{INTRODUCTION}

Social support is associated with numerous psychological benefits, such as improved self-confidence, sense of empowerment, efficiency, and quality of life. Similarly, lack of social support appears to be related to mental manifestations and weaker health perceptions [1]. Four types of supportive behavior are considered as important by House i.e. Emotional support (concern, self-esteem, affect), appraisal support (feedback, affirmation), informational support (information, suggestion, advice), instrumental support (time, money, aid in labor). Perceived social support from family, friends and significant others are an essential determinant of positive adjustment following trauma [2]. According to a scholar, social support can be derived from sources at the workplace and outside the workplace [3]. At the workplace, the sources of social support include the supervisor and co-workers, while sources of extra-organizational support include family and friends. Studies also show that social support outside of work, such as that provided by spouses and friends, may have a positive impact on work-family balance by reducing work-family conflict $[4,5]$. Social support is a mutual process and a source of interaction that provides comfort, assistance, and encouragement. It enhances successful compatibility and improves satisfaction and efficient life [6].

A scholar defines marital adjustment as, "the state in which there is an overall feeling between husband and wife, of happiness and satisfaction with their marriage and with each other [7]. Other scholar did a study in India about marital adjustment and subjective well-being in Indian educated housewives and working women [8]. Their results indicated that working women had better marital adjustment and subjective well-being. Working women reported high scores on general health, life satisfaction and self-esteem measures \& lower scores on hopelessness, insecurity and anxiety whereas the housewives had lower scores on negative affect than the working women. A study by a group of researchers conducted among Swedish women ascertains that heavy domestic responsibility and or a job strain situation are factors that seem to contribute a high level common physical and mental symptom among salaried women of 30-50 years of age [9]. Other researcher also emphasizes the importance of considering the external context of the couple as research has found that both early familial interaction and current situational factors have profound influence on levels of conflict and satisfaction within marriage [10]. Various researches have shown that when a partner elicits a great deal of supportive behavior, love and affection along with spousal care, more marital satisfaction will be experienced by the couple [11]. Other researchers also showed that social support causes one to overcome problems of marital life [12].

\section{CURRENT STUDY}

In married life women had a number of responsibilities to perform therefore she under goes high amount of pressure. The amount of pressure increases if the married women is working. The working women experience financial independence, high self esteem but at the same time face challenge to get enough social support and marital relationship. Above literature of review reveals that there may be relationship between perceived social support and marital relationship. Since there was dearth of studies in this aspect therefore the researcher planned to study Social Support and Marital Adjustment in Married Working women.

\section{METHOD}

\subsection{Participants}

There were 64 married working women participants in the study age ranging from 25-40 years. The data was collected from Bijnor, Uttar Pradesh. 


\subsection{Tools}

\subsubsection{Socio-demographic data sheet}

It was prepared by the investigator to collect information about demographic details.

\subsection{Multidimensional Scale of Perceived Social Support (MSPSS)}

The social support was assessed by MSPSS, a 12- item questionnaire, which was developed by a group of researchers, in order to measure perceived social support from three support domains, family, friends and significant others [13]. MSPSS is rated on a 7-point scale (1=disagree very strongly; $7=$ agree very strongly). The Cronbach alpha values were found to be between .83 and .91 in 3 Turkish samples, where the means were $(M=53.56, S D=16.99)$ for psychiatry, $(M=65.98, S D=15.63)$ for surgery, and $(M=66.42, S D=11.60)$ for normal [14]. Higher scores on the scale indicate perception of positive social support.

\subsection{Marital Adjustment Questionnaire}

Table 1: Demographic Profile of Married Working Women was used to measure marital adjustment developed by Kumar and Rastog in 1976. The MAQ in its final form consists of 25 highly discriminating 'YesNo' type items. The areas of questionnaire are sexual, social and emotional. The questionnaire was also validated against Singh's marital adjustment inventory [15]. The coefficient correlation between the questionnaires for a group was found to be 0.71 with index of reliability of 0.84 .

\subsection{Procedure}

Informed consent was taken prior to the administration of tools. The demographic data sheet, Multidimensional Scale of Perceived Social Support (MSPSS) and Marital Adjustment Questionnaire were administered on 64 married working women participants age ranging from 25-40 years. The participants were briefed about the purpose of the study. Then participants were given the questionnaires and proper instructions for completing the questionnaires. Confidentiality of data was ensured. Data analysis was performed by using Statistical Package for Social Science (SPSS) 21.0 version. Obtained data was analyzed with Pearson product moment correlation.

\begin{tabular}{|l|l|l|l|l|l|}
\hline \multicolumn{1}{|c|}{ Years of Marriage } & \multicolumn{1}{|c|}{ Education } & \multicolumn{1}{c|}{ Occupation } & No of children & Job of Husband & \multicolumn{1}{c|}{ Religion } \\
\hline $\begin{array}{l}42 \text { women above 3 } \\
\text { years }\end{array}$ & $\begin{array}{l}31 \text { MBA/M.Ed./ B. } \\
\text { Tech/Ph. D }\end{array}$ & 29 teachers & 2 Children 30 & 33 Pvt. Job & $28 \mathrm{Hindu}$ \\
\hline $\begin{array}{l}22 \text { women } \\
0-3 \text { years of marriage }\end{array}$ & 14 Post Graduate & 18 Office jobs & 1 Child 16 & 19 Govt. Jobs & 23 Muslim \\
\hline & 10 Graduate & 17 Miscellaneous & $\begin{array}{l}\text { More than two } \\
\text { children 12 women }\end{array}$ & 12 Business & 8 Sikh \\
\hline & 9 Inter and high school & & No child 6 women & & 5 Christian \\
\hline
\end{tabular}

Table 1 revealed that forty-two working women completed more than three years of marriage and twenty-two below three years. In the total sample thirty working women either had done professional course of above post graduation. Fourteen were post graduate, ten graduates and nine high school to intermediate. In terms of profession twenty-nine were teachers, eighteen office jobs and seventeen miscellaneous. Thirty women had two children, sixteen one child, twelve more than two and six had no child. The husbands thirty-three working women were on private jobs, nineteen Government jobs and twelve husbands were doing business. Out of total sample twenty-eight Hindus, twenty-three Muslims, eight Sikh and five Christians.

\section{RESULT AND DISCUSSION}

Table 2: Summary of Pearson Correlation Coefficient between family, friends, significant others, Overall social support and Marital Adjustment.

\begin{tabular}{|c|c|c|c|c|c|}
\hline & Family & Friends & Others & Social Support & Marital Adjustment \\
\hline Family & $\begin{array}{l}1 \\
64\end{array}$ & & & & \\
\hline Friends & $\begin{array}{l}.438^{* *} \\
000 \\
64\end{array}$ & $\begin{array}{l}1 \\
64\end{array}$ & & & \\
\hline Significant Others & $\begin{array}{l}.203 \\
.108 \\
64\end{array}$ & $\begin{array}{l}.367^{* *} \\
.003 \\
64\end{array}$ & $\begin{array}{l}1 \\
64\end{array}$ & & \\
\hline Overall Social Support & $\begin{array}{l}.712^{* *} \\
.000 \\
64\end{array}$ & $\begin{array}{l}.758^{* *} \\
.000 \\
64\end{array}$ & $\begin{array}{l}.604^{* *} \\
.000 \\
64\end{array}$ & $\begin{array}{l}1 \\
64\end{array}$ & \\
\hline Marital Adjustment & $\begin{array}{l}.277^{*} \\
.027 \\
64\end{array}$ & $\begin{array}{l}.348^{* *} \\
.005 \\
64\end{array}$ & $\begin{array}{l}.226 \\
.073 \\
64\end{array}$ & $\begin{array}{l}.436^{* *} \\
.000 \\
64\end{array}$ & $\begin{array}{l}1 \\
64\end{array}$ \\
\hline
\end{tabular}

*Correlation is significant at the 0.01 level (2-tailed).

${ }^{*}$ Correlation is significant at the 0.05 level (2-tailed).

Table- 2 revealed that there was significant correlation between family and marital adjustment at .05 level. Friends are significantly correlated with marital adjustment at .01 level. According to Caplan el al. (1975), social support can be derived from sources at the workplace and outside the workplace. At the workplace, the sources of social support include the supervisor and co-workers, while sources of extra-organizational support include family and friends. A similar study conducted by a group of scholars found that women living in joint family setup received more social support form important figures in their life than the women living in nuclear family setup [16]. Significant others have not been found to be correlated with marital adjustment at .05 level. Since significant others are in the outer circle therefore because of busy schedule working women has low level of interaction with them and hence their social support is not linked with the marital adjustment among working women. Overall social support was found to be significantly correlated with marital adjustment at .01 level. According to a scholar, social support is a mutual process and a source of interaction that provides comfort, assistance, and encouragement. It enhances successful compatibility and improves satisfaction and efficient life. A study by a previous scholar conducted among Swedish women ascertains that heavy domestic responsibility and or a job strain situation are factors that seem to contribute a high level common physical and mental symptom among salaried women of 30-50 years of age. A scholar also showed that social support causes one to 
overcome problems of marital life.

\section{CONCLUSION}

In short, maintaining marital relationship is challenging task for married working women since she has multiple role to play at a time. In the journey of married life social support from all corner play vital role. In the present study, family, friends and overall social support were significantly correlated with the marital adjustment in married working women. These finding can be used to remove marital adjustment difficulties prevailing in the society.

\section{ACKNOWLEDGEMENT}

Our special thanks to all the participants of the study for their co-operation and other supportive behavior.

\section{REFERENCES}

[1] McCorkle, B.H., Rogers, E.S., Dunn, E.C., Lyass, A., Wan, Y.M. 2008. Increasing social support for individuals with serious mental illness: Evaluating the compeer model of intentional friendship. Community Mental Health Journal, 44, 359-366. doi: 10.1007/s10597-008-9137-8. [PubMed] [ Cross Ref]

[2] Kinsinger, D.P., Penedo, F.J., Antoni, M.H., Dahn, J.R., Lechner, S., Schneiderman, N. 2006. Psychosocial and demographic correlates of benefit-finding in men treated for localised prostate cancer. PsychoOncology, 15, 954-961.

[3] Caplan, R.D., Cobb, S., French, J.R.P., Harrison, R.Y., Pinneau, S.R. 1975. Job Demands and Worker Health. U.S. Department of Health, Education and Welfare. HEW Publication No. (N10SH) 75-160.

[4] Carlson, D., Perrewe, P. 1999. The role of social support in the stressorstrain relationship: an examination of work-family conflict, Journal of Management, 25(4), 513-40.

[5] Greenhaus, J., Parasuraman, S. 1994. Work-family conflict, social support and wellbeing, in Davidson, M. and Burke, R. (Eds), Women in Management: Current Research Issues, Paul Chapman, London, 213-29.
[6] Pender, N.J., Murdaugh, C.L., Parson, M.A. 2001. Health promotion in nursing practice. Philadelphia: Upper Saddle River, New Jersey.

[7] Sinha, S.P., Mukerjee, N. 1990. Marital adjustment and personal space orientation. Journal Social Psychology, 130, 633-9.

[8] Nathawat, S.S., Mathur, A. 1993. Marital Adjustment and Subjective Well-Being in India Educated Housewives and Working Women. The Journal of Psychology, 127(3), 353-358.

[9] Krantz, G., Ostergreuv, P.O. 2001. Double Exposure- The combined impact of domestic responsibilities and job strain on common symptoms in employed Swedish women. European Journal of Public Health, 11 (4), 413-419.

[10] Fincham, F.D., Beach, S.R.H. 2010. Marriage in the New Millennium: A Decade in Review. Journal of Marriage and Family, 72,630-649.

[11] Cutrona, C.E., Suhr, J.A. 1994. Social support communication in the context of marriage: An analysis of couples' supportive interactions. In B. R. Burleson, T. L. Albrecht \& I.G. Sarason (Eds.), Communication of social support: Messages, interactions, relationships, and community, 113-135.

[12] Dehle, C., Landers, J.E. 2005. You can't always get what you want, but can you get what you need? Personality traits and social support in marriage. Journal of social and clinical Psychology, 24 (7), 1051-1076.

[13] Zimet, G.D., Dahlem, N.W., Zimet, S.G., Farley, G.K. 1988. The Multidimensional Scale of Perceived Social Support. Journal of Personality Assessment, 52, 30-41.

[14] Eker, D., Arkar, H., Yaldiz, H. 2000. Generality of support sources and psychometric properties of a scale of perceived social support in Turkey. Social Psychiatry and Psychiatric Epidemiology, 35, 228-233.

[15] Kumar, P., Rastogi, K. 1976. Development of Marital Adjustment Questionnaire. Indian Journal of Psychology, 51(4), 346-348.

[16] Kazmi, F.S., Khan, M., Tahir, R., Dil, S., Khan, M.A. 2013. Relationship between social support and postpartum Depression. Annals of Pakistan Institute of Medical Sciences, 9(4), 110-113 